\title{
Limnological Assessment of Heavy Metals Concentration in Water and Sediment of Oguta Lake, South-East Nigeria, Nigeria
}

\author{
E.T Adebayo ${ }^{1 *}$, T.J C-Oluwatosin ${ }^{2}$, P.C. Nneji ${ }^{3}$ \\ ${ }^{I}$ Department of Fisheries and Aquaculture Technology, Federal University of Technology, Owerri, Nigeria \\ ${ }^{2}$ Department of Rural Development and Gender issues, Agricultural and Rural Management Training Institute, \\ Ilorin, Nigeria \\ ${ }^{3}$ Department of Fisheries and Aquaculture Technology, Federal University of Technology, Owerri, Nigeria \\ *Corresponding Author: E.T Adebayo, Department of Fisheries and Aquaculture Technology, Federal \\ University of Technology, Owerri, Nigeria
}

\begin{abstract}
Oguta Lake was the largest natural lake in Imo State, south-east Nigeria. It is used for several purposes ranging from Agriculture, domestic, industrial, artisanal fishing, transportation, and tourism, and constantly received wastes and effluents from these activities. A study of the physico-chemical parameters and heavy metal accumulation in water and sediment of Ogutalake was conducted to ascertain the effects of the anthropogenic activities on the lake between Julys to September, 2016, in order to add to the basement information on the lake. Iron concentration in water sample was only revealed to exceed NESREA recommendation standard for aquatic life, and Iron was shown has the highest concentration in the sediment. A further significant spatial variation in some physico-chemical and heavy metal accumulation across the sampled stations in the lake was observed. Erosion of the ad journey lands and run-off of sewages was found to be accounted for the changes.
\end{abstract}

Keywords: Physico-chemical parameters, Oguta Lake, Heavy metals

\section{INTRODUCTION}

Water is a natural resource which serves various purposes to man in every area of his life. According to Baroniet al., (2007), water plays important role in the world economy, as it serves as universal solvent for wide range of chemical substances.

Heavy metal pollution is a rising environmental problem of great concern as they are non-degradable and persistent, thus requires immediate attention. These metals are used in various industries from which effluents are consequently discharged into the aquatic environment. The most anthropogenic sources of metals are industrial, petroleum contamination and sewage disposal (Santos et al., 2005). The agricultural drainage water containing pesticides and fertilizers and effluents of industrial activities and runoffs in addition to sewage effluents supply the water bodies and sediment with huge quantities of inorganic anions and heavy metals (ECDG, 2002).

Lake sediments are normally the final pathway of both natural and anthropogenic components produced or derived to the environment. Sediment quality is a good indicator of pollution in water column, where it tends to concentrate the heavy metals and other organic pollutants. Under changing environmental conditions, these sediment bound heavy metals may be remobilized and enter the water or food chain. Aquatic animals, including fish bio-accumulate trace metals in considerable quantity (Iboket al., 1989, and Burger et al., 2002), hence they are finally transferred to other animals including humans through the food chain (Etuk and Mbonu, 1999).

Though some metals are essential for life, but if an individual's intake exceeds a certain threshold, toxicity may develop. Ingestion of heavy metals through drinking water and eating contaminated sea foods may cause various diseases such as anemia, neuropsychological effects, liver diseases, gastrointestinal pathologies, teratogenic implications (Needleman \& Bellinger, 1991). Moreover, it is known that the DNA-damaging effects of certain metals in humans can lead to induction of cancer and a decrease of fertility (Snow, 1992). 
Limnological Assessment of Heavy Metals Concentration in Water and Sediment of Oguta Lake, SouthEast Nigeria, Nigeria.

Oguta Lake is extensively being used for several activities ranging from domestics, agricultural, fishing, recreational, means of transportation of logs, sand dredging, among others. Beside the sewage discharges and the erosion run-off from domestics, agricultural and other municipal generated wastes into the lake, its various tributaries such as River Njaba, River Utu and River Awbuna also empties all sorts of anthropogenic wastes along there course into the lake. Thus, the need to investigate the concentration levels of some heavy metal in the Lake.

\section{Materials AND Methods}

\subsection{Description of Study Area}

Oguta Lake is situated in Oguta Local Government Area of Imo State; it constitutes the largest natural Lake in Imo State, South-eastern Nigeria. It is bounded on Latitudes $05^{\circ} 41^{\prime}$ to $05^{\circ} 44^{\prime} \mathrm{N}$ and Longitudes $06^{\circ} 41^{\prime}$ to $06^{0} 50^{\prime} \mathrm{E}$, with an elevation of $50 \mathrm{~m}$ above sea level. It occupies a surface area ranging between $1.8 \mathrm{~km}^{2}$ and $2.5 \mathrm{~km}^{2}$, a shoreline length of $10 \mathrm{~km}$, and maximum and mean depths of $8.0 \mathrm{~m}$ and $5.5 \mathrm{~m}$ respectively (Nfor and Akaegbobi, 2012)(Figure 1). The Lake further empties into River Niger in Anambra State through Orashi River. The climate is tropical rain forest with two distinct seasons, a dry season which lasts from October to March, and the rainy season which lasts from April to September (Nnaji, 2011). The temperature is generally high with an average of $27^{\circ} \mathrm{C}$, hottest months are February and March when the temperature rises to between $33^{\circ} \mathrm{C}$ and $35^{\circ} \mathrm{C}$. The Lake served as Biafran Army marine base during the Nigerian Civil war (Nfor and Akaegbobi, 2012).

Oguta was one of the first territories used by the British to advance into the Igbo hinterland. As of 2012, Oguta's population was estimated at 20,096.River routes from the Lake thorough AwoOmamma, Orashi River, River Ndoni, River Awbuna, River Niger, and to the coat makes Oguta town an important Centre of international trade.

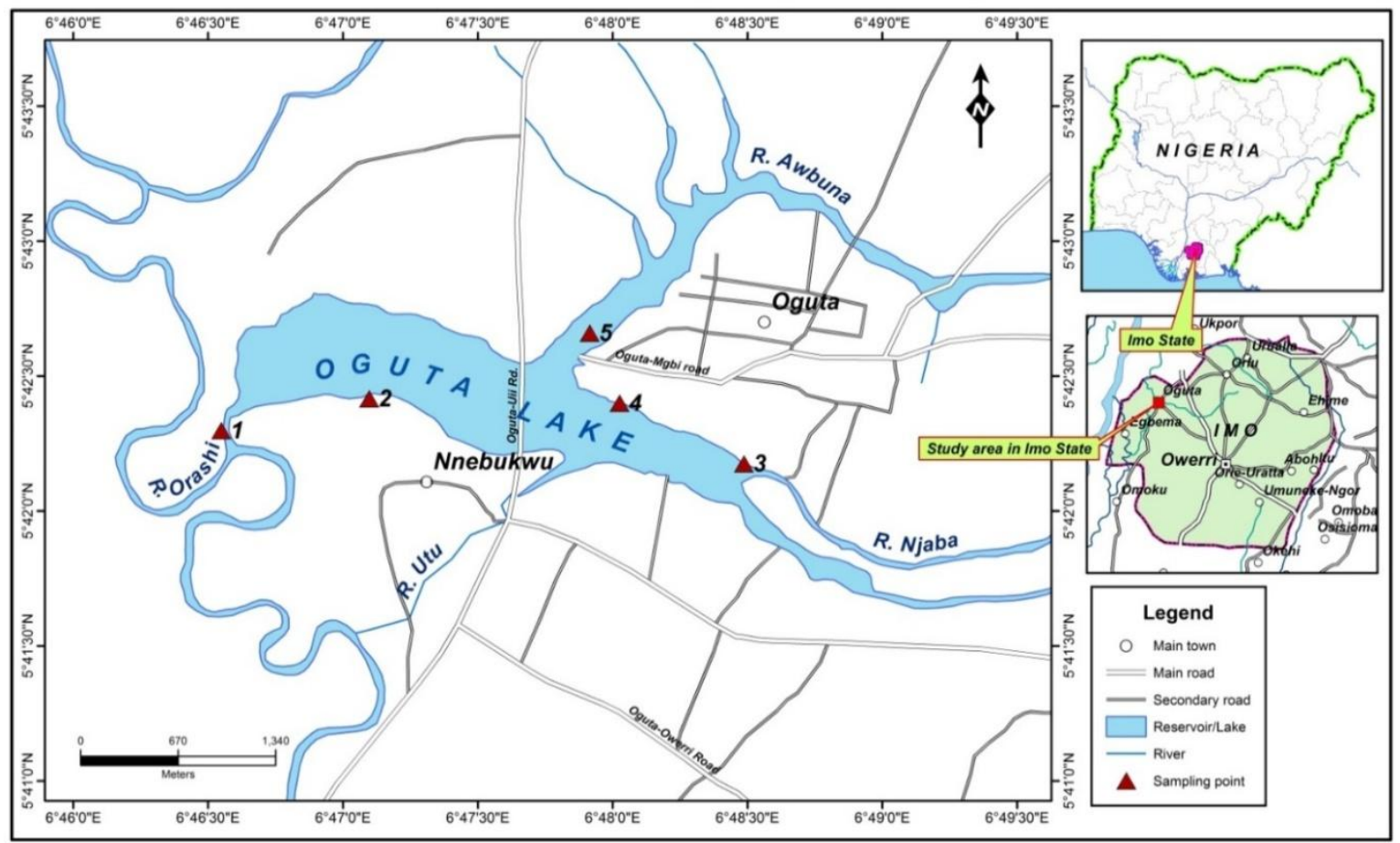

Figure1: Map of Oguta Lake showing the Sampling Station (Source: Cartographic Unit, Department of Geography, University of Ibadan, and Ibadan. June, 2016)

\subsection{Experimental design}

Five sampling stations were selected with respect to anthropogenic activities around the Lake. The stations' co-ordinates were taking using a Global Positioning System (GPS) Naval 300 (Figure 1).Bimonthly samplings (two weeks interval) were carried out between the hours of 8.00am-11.00am for three months (July - September, 2016).

Physico-chemical parameters like temperature, transparency, water current, dissolved oxygen and were measured in situ using Mercury-in-glass Thermometer, Secchi disc, floater and stop watch, and 
Limnological Assessment of Heavy Metals Concentration in Water and Sediment of Oguta Lake, SouthEast Nigeria, Nigeria.

dissolved Oxygen meter (model-5509) respectively (APHA, 1998). While surface water samples for other chemical parameters were collected in 1L sterile plastic bottle and transported to the Departmental laboratory of Fisheries and Aquaculture Technology, Federal University of Technology, Owerri, Imo state prior analysis. Likewise, Surface water samples for heavy metals were collected in one litter sterile plastic bottle and preserved with $2 \mathrm{ml}$ nitric acid, while Sediments sample were haul into a pre-labeled polythene bag using Echman grab and air dry in the laboratory prior analysis. Heavy metals samples were analyzed in FATLAB Nigeria Company Laboratory, Ibadan, Nigeria. All the analysis was done using a standard analysis method as described by APHA (1998).

\section{RESULTS AND DISCUSSION}

The descriptive results of the Physico-chemical parameters of Oguta Lake are shown in Table 1. Of all the parameters measured, only Iron concentration $(0.17 \pm 0.017 \mathrm{mg} / \mathrm{L})$ in water was found to exceed the NESREA standard recommendation limit for fish fauna. Accumulation of this metal might be accounted for by degradation of several cans materials that were eroded into the lake during the rainfall, as well as direct deposition of these cans during the picnics visit. Similarly, run-off from the corroded Iron roof that was drained into the lake through the recent channeling of the Oguta town drainage system into the lake might as well contributed to the noticeable increase of Iron concentration in the water of the lake. The higher recorded concentration values of the heavy metals in the sediment follows a general phenomenon of water sediment to adsorb and accumulate these materials prior its release after the maximum adsorption capacity has being exceeded. Hence, Iron concentration in the sediment might have said to have attained it maximum adsorption level in the sediment resulting into it subsequent release back into the water and thereby increase it concentration in the water.

Table1. Descriptive statistics of the Physico-chemical parameters of Oguta Lake, between July and September, 2016

\begin{tabular}{|l|l|l|l|l|l|l|}
\hline \multicolumn{1}{|c|}{ Parameter } & $\begin{array}{c}\text { Minimu } \\
\mathbf{m}\end{array}$ & $\begin{array}{c}\text { Maximu } \\
\mathbf{m}\end{array}$ & \multicolumn{1}{|c|}{ Range } & \multicolumn{1}{|c|}{ Mean } & \multicolumn{1}{|c|}{$\begin{array}{c}\text { WHO } \\
\mathbf{( 1 9 9 8})\end{array}$} & $\begin{array}{c}\text { NESRE } \\
\mathbf{A}(\mathbf{2 0 1 1})\end{array}$ \\
\hline Temperature $\left({ }^{\circ} \mathrm{C}\right)$ & 25.50 & 29.00 & 3.50 & $26.70 \pm 0.16$ & $30.00-32.00$ & ${ }^{\mathrm{a}}$ \\
\hline Current $(\mathrm{m} / \mathrm{s})$ & 2.37 & 26.25 & 23.88 & $8.41 \pm 0.92$ & & \\
\hline Transparency $(\mathrm{m})$ & 0.43 & 2.95 & 2.52 & $1.55 \pm 0.13$ & & $\mathrm{NS}$ \\
\hline $\mathrm{DO}(\mathrm{ppm})$ & 3.10 & 11.20 & 8.10 & $7.02 \pm 0.31$ & $>5.00$ & Not \\
\hline Total Hardness $(\mathrm{ppm})$ & 8.00 & 48.00 & 40.00 & $29.19 \pm 1.80$ & 150.00 & \\
\hline $\mathrm{pH}$ & 5.00 & 6.50 & 1.50 & $5.83 \pm 0.09$ & $7.00-8.50$ & $6.50-8.50$ \\
\hline $\mathrm{Ch}$ loride (ppm) & 16.00 & 36.00 & 20.00 & $22.93 \pm 0.91$ & 250.00 & 300.0 \\
\hline Nitrate-Nitrogen $(\mathrm{ppm})$ & 0.05 & 0.10 & 0.05 & $0.058 \pm 0.003$ & 0.50 & 9.10 \\
\hline $\mathrm{Alkalinity}(\mathrm{ppm})$ & 12.00 & 44.00 & 32.00 & $29.75 \pm 1.44$ & 200.00 & $\mathrm{NS}$ \\
\hline $\mathrm{CO}_{2}(\mathrm{ppm})$ & 5.00 & 13.00 & 8.00 & $7.65 \pm 0.42$ & $<10.00$ & $\mathrm{NS}$ \\
\hline $\mathrm{Mn}_{\mathrm{W}}(\mathrm{mg} / \mathrm{L})$ & 0.00 & 0.15 & 0.15 & $0.01 \pm 0.01$ & $0.10-0.50$ & $\mathrm{NS}$ \\
\hline $\mathrm{Cu}_{\mathrm{W}}(\mathrm{mg} / \mathrm{L})$ & $\mathrm{ND}$ & $\mathrm{ND}$ & $\mathrm{ND}$ & $\mathrm{ND}$ & $<0.50$ & 0.001 \\
\hline $\mathrm{Pb}_{\mathrm{W}}(\mathrm{mg} / \mathrm{L})$ & $\mathrm{ND}$ & $\mathrm{ND}$ & $\mathrm{ND}$ & $\mathrm{ND}$ & - & 0.01 \\
\hline $\mathrm{Fe}_{\mathrm{W}}(\mathrm{mg} / \mathrm{L})$ & 0.10 & 0.60 & 0.50 & $0.17 \pm 0.017$ & 0.30 & 0.05 \\
\hline $\mathrm{Mn}_{\mathrm{S}}(\mathrm{mg} / \mathrm{g})$ & 0.91 & 52.29 & 51.39 & $17.22 \pm 2.77$ & - & - \\
\hline $\mathrm{Cu}_{\mathrm{S}}(\mathrm{mg} / \mathrm{g})$ & 0.00 & 27.03 & 27.03 & $6.53 \pm 1.44$ & - & - \\
\hline $\mathrm{Pb}_{\mathrm{S}}(\mathrm{mg} / \mathrm{g})$ & 0.00 & 45.46 & 45.46 & $9.58 \pm 2.75$ & - & - \\
\hline $\mathrm{Fe}_{\mathrm{S}}(\mathrm{mg} / \mathrm{g})$ & 261.23 & 45114.00 & 44852.77 & $5788.94 \pm 1651.4$ & - & - \\
\hline
\end{tabular}

Note: $M n W=$ Manganese in water, $P b W=$ Lead in water, CuW= Copper in water, FeW= Iron in water, MnS= Manganese in sediment, $P b S=$ Lead in sediment, $C u S=$ Copper in sediment, FeS=Iron in sediment, ND = Not Detected, NS = Not Specified, DO = Dissolved Oxygen, and a Except in mixing zones, temperature increases by a 7-day average of the daily maximum temperatures shall not be more than $0.3 o C$ above natural background conditions

\subsection{Spatial Variation in Physico-Chemical Parameters}

The physico-chemical parameters of Oguta Lake, like any other aquatic ecosystem, are prone to ecological imbalances resulting from both natural and anthropogenic impacts. The marked spatial variation and significant differences in most of the physico-chemical parameters of the water and sediment (Table 2) indicate different environmental conditions. These variations may be related to 
Limnological Assessment of Heavy Metals Concentration in Water and Sediment of Oguta Lake, SouthEast Nigeria, Nigeria.

patterns of water use, and run-off that brought in different allochthonous materials during rainfall. Similar observation has been reported by Ayoadeet al. (2006); Atobatele and Ugwumba (2008); Mustapha (2009), and Edward and Ugwumba (2010).

Table2. Spatial variation in Physico-chemical parameters of Oguta Lake between July and September, 2016 at $P<0.5$

\begin{tabular}{|c|c|c|c|c|c|}
\hline \multirow[t]{2}{*}{ Parameters } & \multicolumn{5}{|c|}{ Sampling stations } \\
\hline & Station 1 & Station 2 & Station 3 & Station 4 & Station 5 \\
\hline Temperature $\left({ }^{\circ} \mathrm{C}\right)$ & $26.500^{\mathrm{a}}$ & $26.7500^{\mathrm{a}}$ & $26.0833^{\mathrm{a}}$ & $26.9167^{\mathrm{a}}$ & $27.0933^{\mathrm{a}}$ \\
\hline Current $(\mathrm{m} / \mathrm{s})$ & $8.2233 b^{c}$ & $12.5800^{\mathrm{a}}$ & $6.9367^{\mathrm{bc}}$ & $5.2200^{c}$ & $9.0700^{\mathrm{b}}$ \\
\hline Transparency (m) & $1.7267^{b}$ & $1.4633^{\mathrm{bc}}$ & $2.4767^{\mathrm{a}}$ & $1.1433^{\mathrm{cd}}$ & $0.7533^{\mathrm{d}}$ \\
\hline DO (ppm) & $6.3167^{\mathrm{a}}$ & $7.1500^{\mathrm{a}}$ & $7.5403^{\mathrm{a}}$ & $7.4667^{\mathrm{a}}$ & $6.8800^{\mathrm{a}}$ \\
\hline Hardness (ppm) & $37.8333^{\mathrm{a}}$ & $28.3333^{\mathrm{ab}}$ & $27.7500^{\mathrm{ab}}$ & $33.400^{\mathrm{a}}$ & $19.3333^{b}$ \\
\hline $\mathrm{pH}$ & $5.7500^{\mathrm{ab}}$ & $5.6667^{\mathrm{ab}}$ & $5.9167^{\mathrm{ab}}$ & $5.500^{b}$ & $6.3333^{\mathrm{a}}$ \\
\hline Chloride (ppm) & $29.6667^{\mathrm{a}}$ & $23.3333^{\mathrm{ab}}$ & $19.3333^{\mathrm{ab}}$ & $16.5833^{b}$ & $19.0833^{b}$ \\
\hline Nitrate Nitrogen (ppm) & $0.0500^{\mathrm{b}}$ & $0.0500^{b}$ & $0.0833^{\mathrm{a}}$ & $0.0567^{b}$ & $0.0500^{b}$ \\
\hline Alkalinity (ppm) & $37.3333^{\mathrm{a}}$ & $35.1000^{\mathrm{a}}$ & $26.4000^{b}$ & $24.7333^{b}$ & $24.3333^{b}$ \\
\hline $\mathrm{CO}_{2}(\mathrm{ppm})$ & $6.5667^{\mathrm{a}}$ & $7.3333^{\mathrm{a}}$ & $7.3667^{\mathrm{a}}$ & $8.0000^{\mathrm{a}}$ & $8.9667^{\mathrm{a}}$ \\
\hline $\mathrm{Mn}_{\mathrm{W}}(\mathrm{mg} / \mathrm{L})$ & $0.0600^{\mathrm{a}}$ & $0.0067^{\mathrm{a}}$ & $0.0000^{\mathrm{a}}$ & $0.0133^{\mathrm{a}}$ & $0.0167^{\mathrm{a}}$ \\
\hline $\mathrm{Fe}_{\mathrm{W}}(\mathrm{mg} / \mathrm{L})$ & $0.1733^{\mathrm{ab}}$ & $0.1567^{\text {ab }}$ & $0.1567^{\mathrm{ab}}$ & $0.2767^{\mathrm{a}}$ & $0.1433^{b}$ \\
\hline $\mathrm{Mn}_{\mathrm{S}}(\mathrm{mg} / \mathrm{g})$ & $20.08133^{b}$ & $8.11400^{c}$ & $7.81333^{c}$ & $7.49767^{\mathrm{c}}$ & $42.40633^{\mathrm{a}}$ \\
\hline $\mathrm{Cu}_{\mathrm{S}}(\mathrm{mg} / \mathrm{g})$ & $3.75100^{b}$ & $1.61400^{b}$ & $5.60000^{b}$ & $2.88800^{b}$ & $20.89133^{\mathrm{a}}$ \\
\hline $\mathrm{Pb}_{\mathrm{S}}(\mathrm{mg} / \mathrm{g})$ & $16.45267^{\mathrm{ab}}$ & $0.00000^{b}$ & $4.06333^{b}$ & $6.96267^{b}$ & $31.98800^{\mathrm{a}}$ \\
\hline $\mathrm{Fe}_{\mathrm{S}}(\mathrm{mg} / \mathrm{g})$ & $6143.2467^{b}$ & $1483.1433^{b}$ & $2254.6233^{b}$ & $1401.9633^{b}$ & $20157.3833^{\mathrm{a}}$ \\
\hline
\end{tabular}

Note: Values with same superscripts along same row are not significantly different at $P<0.05 . M n W=$ Manganese in water, $\mathrm{PbW}=$ Lead in water, $\mathrm{CuW}=$ Copper in water, FeW= Iron in water, MnS= Manganese in sediment, $P B S=$ Lead in sediment, $C u S=$ Copper in sediment, FeS=Iron in sediment, ND = Not Detected, NS = Not Specified, $D O=$ Dissolved Oxygen.

\section{CONCLUSION}

Oguta Lake could be regarded as unpolluted as at the period of this study, but the observed results from the physic-chemical parameters in the sediment and the recorded higher Iron concentrations above the NESREA standard recommendation limit for aquatic life reflects some levels of contaminations. Though the lake is said not to potent any health hazard as at the period of this studies but cautions should be made about the uses of the lake as a means of waste discharge by the entire environ.

\section{REFERENCES}

[1] American Public Health Association- APHA. 1998. Standard Methods for the Examination of Water and Wastewater. $20^{\text {th }}$ ed. APHA/AWWA/WEF: Washington DC. USA. 1213p

[2] Atobatele, O.E. and Ugwumba, O.A 2008.Seasonal Variation in the Physico-chemistry of a Small Tropical Reservoir (Aiba Reservoir, Iwo, Osun, Nigeria). African Journal of Biotechnology Vol. 7(12):62-171.

[3] Ayoade, A.A, Fagade, S.O. and Adebisi A. A. 2006..Dynamics of Limnological Features of Two ManMade Lakes in Relation to Fish Production. African Journal of Biotechnology 5(10): 1013-1021.

[4] Baroni, L., Cenci, L., Tettamani, M., Berati, M. 2007. Evaluating the Environmental Impact

[5] Burger, J., Gaines, K.F., Boring, S., Stephens, L., Snodgrais, J., Dixon, C., McMahon, M., Shulila, S., Shulila, T. and Goshfeld, M. 2002. Metal levels in fish form the Savannah River: Potential hazards to fish and other receptors. Environ. Res., 89: 85-97.

[6] ECDG. 2002. European Commission DG ENV. E3 Project ENV. E.3/ETU/0058. Heavy metals in waste. Final report.

[7] Edward, J.B. andUgwumba, A.A.A. 2010.Physico-Chemical Parameters and Plankton Community of Egbe Reservoir, Ekiti State, Nigeria. Research Journal of Biological Sciences.Vol. 5(5), pp 356-367.

[8] Etuk, E. U. I. and Mbonu, C. O. 1999.Comparison of trace and toxic metal contamination in periwinkles from qua Iboe River (Ibeno) and Cross River (Oron). Proceeding of the 23rd Annual conference of the Nigerian Institute of food science and Technology held at Abuja October 25-27 $7^{\text {th }}$

[9] Ibok, U.J., Udosen, E.D. and Udoidiong, O.M. 1989. Heavy metals in fishes from some 
[10] Mustapha M.K. 2009.Phytoplankton assemblage of a small, shallow, tropical African reservoir.Int. J. Trop. Biol. Vol. 57 (4): 1009-1025,

[11] National Environmental Standards and Regulations Enforcement Agency (NESREA) 2011. National Environmental (surface and groundwater quality control) Regulations. Federal Republic of Nigeria Official Gazette No. 49, vol.1 98, Government Notice No.136. The Federal Government Printer, Lagos, Nigeria.FGP 71/72011/400(OL 46).

[12] Needleman, H. L. and Bellinger, D. 1991. The health effects of low level exposure to lead. Annual Rev. Public Health, 12: 111-140

[13] Nfor, B. N. and Akaegbobi, I. M. 2012. Inventory of the Quaternary Geology and the Evolution of the Oguta Lake, in Southeastern Nigeria World Journal of Engineering and Pure and Applied Sci., 2:2.

[14] Nnaji, O. A. 2011. An assessment of Developmental potential of Oguta Lake as a tourist destination. Review of Tourism Research.9 (6), 266p. Of Various Dietary Patterns Combined with Different Food Production Systems. European Journal of Clinical Nutrition 61(2): 279-286 doi:10.1038

[15] Santos, I.R., Silva-Filho, V., Schaefer, C.E., Albuquerque-Filho, M.R., and Campos, L.S. 2005. Heavy metal contamination in coastal sediments and soils near the Brazilian Antarctic station, king George Island. Marine pollution Bulletin, 50 (2005), pp.85-194.

[16] Snow, E.T. 1992. Metal Carcinogenesis: Mechanistic Implications, Pharmacol.Ther. 53, 31-65. Streams in IkotEkpene area of Nigeria. Nig. J. Technol. Res., 1: 61- 68.

Citation: E.T Adebayo, et al., "Limnological Assessment of Heavy Metals Concentration in Water and Sediment of Oguta Lake, South-East Nigeria, Nigeria.", International Journal of Innovative Studies in Aquatic Biology and Fisheries, vol. 3, no. 3, p. 18-22, 2017. http://dx.doi.org/10.20431/2454-7670.0303004

Copyright: (C) 2017 Authors. This is an open-access article distributed under the terms of the Creative Commons Attribution License, which permits unrestricted use, distribution, and reproduction in any medium, provided the original author and source are credited. 